\title{
Looking for Relics: Native Legend and the "acid test of scientific investigation"
}

\section{Lee Schweninger}

\section{(2) OpenEdition}

\section{Journals}

\section{Electronic version}

URL: http://journals.openedition.org/elohi/735

DOI: 10.4000/elohi.735

ISSN: 2268-5243

\section{Publisher}

Presses universitaires de Bordeaux

\section{Printed version}

Date of publication: 1 January 2014

Number of pages: $69-88$

ISBN: 979-10-300-0021-4

ISSN: 2431-8175

\section{Electronic reference}

Lee Schweninger, "Looking for Relics: Native Legend and the "acid test of scientific investigation" », ELOHI [Online], 5-6 | 2014, Online since 01 January 2015, connection on 20 April 2019. URL : http:// journals.openedition.org/elohi/735; DOI : 10.4000/elohi.735 


\section{Looking for Relics: Native Legend and the "acid test of scientific investigation"}

The people from Laguna and Acoma Pueblos in west-central New Mexico tell a story about Enchanted Mesa that goes something like this: One day long ago ... (i.e., perhaps hundreds and hundreds of years ago), the people climbed down from the mesa where they lived to do the hoeing and watering of their crops. While they were busy tending the fields, a severe thunderstorm came up, as desert storms are wont to do, and washed away the stone ladder, the only means of access to the top of the mesa. Because they were thus unable to return to their homes, they had to find another place to live, and they settled what is now Acoma Pueblo a few miles to the south. In a reference to Acoma, the sky city, as the site of their new home, anthropologist Charles Lummis sums up a part of the story:

How old is that mysterious sky city no man may know. In the far gray past Acoma stood atop the Mesa Encantada, three miles north; but a mighty throe of nature toppled down the vast ladder-rock which gave sole admit to that dizzy perchtwice as high as the new Acoma. The people were left homeless in the plain, where they were tending their crops; and three doomed women, left at home, were shut aloft to perish upon the accursed cliff. But when the Spanish world-finders saw this magic valley, the present Acoma was already an ancient city" (Lummis 43-44).

What makes this story especially interesting in my context here is another, related story. Hearing the account of the former inhabitants of Enchanted Mesa described above, William Libbey, a science professor from Princeton University, scaled the mesa in the summer of 1897. According to the record, his desire was to disprove the Pueblo version of their history. Because of the mesa's height and the sheerness of its sides, he argued, the people could not have ever lived 
on top of it. With a combination of ropes and pulleys, he managed to ascend that apparently inaccessible mesa, where he and a newspaper reporter spent a few hours looking for signs of former habitation. They found none. Libbey thus exclaimed in triumph: "Romantic Indian legend can never stand the acid test of scientific investigation" (Hodge Letter). Somewhat later (3-4 September 1897) Frederick Hodge, an archeologist (associated with Columbia University and later with the Smithsonian Institution in Washington, DC), climbed the same mesa and found an assortment of relics, proving, he asserted, that Pueblo people had indeed lived on top of the mesa and that the oral narrative relating the thunderstorm and flash flood could well be true. He writes that the "abundance of ancient relics in the talus, the distinct remains of the ladder-trail, the specimens found on the summit coupled with the destruction wrought by nature, the tradition itself-all testify to the former habitation of the site" (Hodge, "Enchanted", 284). Adolph Bandolier, another anthropologist and contemporary of Hodge, maintains that "Whatever may be true in this folk-tale about the rock of Katzim-a (as the Mesa Encantada is called by the Acomas), it is certain that its appearance and the amount of detritus accumulated around its base give some color to the legend" (Bandelier, quoted in Hodge, "Verification" 300). Specifically significant, as I see it, is that Hodge himself submits that science might do well to listen to Indian tradition as related through oral narrative: "To the Acomas", he writes, "Katzimo is still enchanted, and as a subject in the study of mysticism the man of science must yet regard it. The lore of a millennium is not undone by a few hours of iconoclasm" (Hodge, "Enchanted", 284).

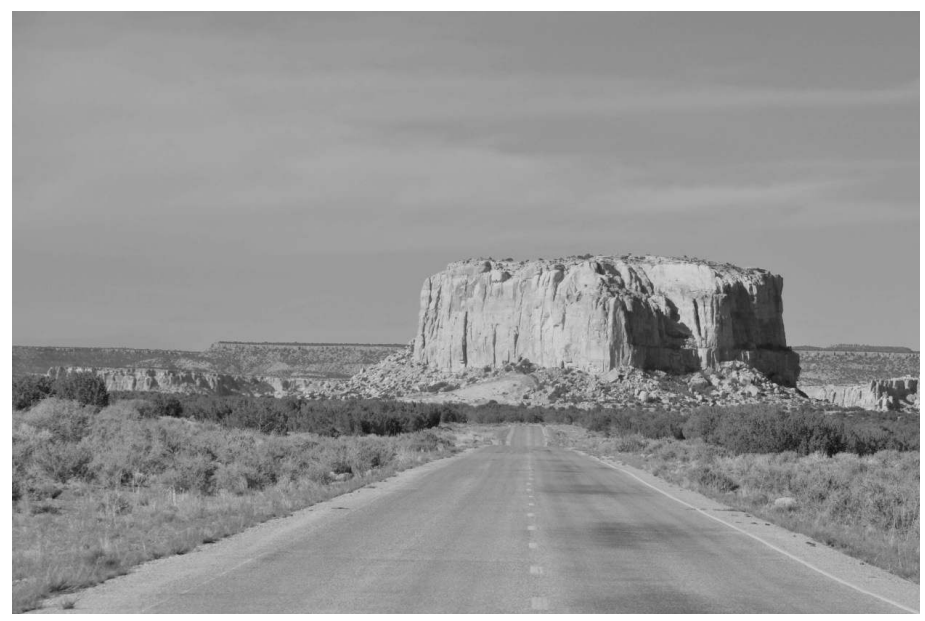

Enchanted Mesa, New Mexico. Photo taken by the author. 2013.

Using as a springboard this particular example of how Western science and Indigenous oral tradition can be seen to butt heads and how it suggests that 
historical or scientific "fact" can be politically manipulated and manipulative, I argue that, according to many contemporary Native American writers, there is a need for all people to recognize the validity of story in the context of what it is that the land, the environment-whether a mesa, a prairie, a rainforest, or an ocean-has to offer human beings.

The narrative relating the history of the Enchanted Mesa is but one of many instances in which oral narrative, initially doubted by scientists or historians, has ultimately been corroborated. Clifford Trafzer recounts an instance when Navajo elders were able to discover the cause of a widespread illness when Western medicine was at a loss: "This oral transmission of [Indigenous] scientific knowledge assisted investigators in solving the mystery illness ..." (Trafzer 1850). Similarly, Deborah McGregor refers to an account by Karen Roberts of "scientists who did not believe the legend of giant beavers until archaeologists found fossils to confirm oral evidence and traditional knowledge" (McGregor 408, note 42; see Roberts 34). In a similar context, Vine Deloria, Jr asks this: "Why is such knowledge only valid and valuable when white scientists document and articulate it?" (Red Earth 59).

As a number of scholars have argued, the West's attitude toward and its willingness to accept the validity of what has come to be called Indigenous knowledges are inseparable from the colonial enterprise in general; that is to say, the dominant, mainstream attitude toward Indigenous knowledge is indicative of a colonial attitude toward Indigenous peoples and their knowledges in general. In representing and insisting on the validity of alternative viewpoints, American Indian writers thus take part in a form of decolonization. This essay, then, traces the topic of Western versus non-Western ways (specifically Indigenous North American ways) of imagining the environment and understanding the "resources" of the natural world as several different Native American writers present it. I suggest that these writers advocate the importance of challenging and simultaneously harmonizing Western scientific worldviews and Native ontological and epistemological schemes. In so doing, their literature takes steps in the process of decolonization.

Although this is not an essay on Indigenous knowledge, per se, it is important to offer a definition and to linger a moment over an articulation of its connection with that colonial enterprise. Simply put, Indigenous knowledge combines the knowledges Indigenous peoples hold and practice worldwide, and have held, developed, and practiced for millennia. Pamela Colorado, who is credited with coining the phrase "Indigenous Science", maintains that Indigenous knowledge results from a science that effectively "synthesizes information from the mental, physical, social and cultural/historical realms" (50). According to David Gordon and Shepard Krech in the introduction to their book-length 
collection of essays, Indigenous knowledge "offers an alternative to the powerknowledge nexus of Western thought, and yet it introduces its own modalities of power" (1). Tewa Pueblo writer Gregory Cajate maintains that "Coming-toknow is the goal of Indigenous science, a different goal from that of Western science" (Cajate 81). That Indigenous knowledge is defined in contrast to a Western worldview makes manifest its integral connection with the colonial legacy. As Deborah McGregor writes, "The recognition of Indigenous Knowledge coincides with the increasing assertion by Indigenous people of their rights and the recognition of these rights by the international community" (McGregor 389). Leanne Simpson states the connection perhaps more bluntly: "Our knowledge comes from the land, and the destruction of the environment is a colonial manifestation and a direct attack on Indigenous Knowledge and Indigenous nationhood" (Simpson 377). Furthermore, she argues, "Recovering and maintaining Indigenous worldviews, philosophies, and ways of knowing and applying those teachings in a contemporary context represents a web of liberation strategies Indigenous Peoples can employ to disentangle themselves from the oppressive control of colonizing state governments" (Simpson 373). Angela Cavender Wilson argues that "recovery of Indigenous knowledge is a conscious and systematic effort to revalue that which has been denigrated and revive that which has been destroyed. It is about regaining the ways of being that allowed our peoples to live a spiritually balanced, sustainable existence within our ancient homelands for thousands of years" (Wilson 359).

Where the West has been interested in Indigenous knowledge, it has been primarily to extract specific knowledge that might be immediately helpful for particular Western enterprises. As McGregor puts it, there is "a lack of respect for traditional knowledge", and thus "For Aboriginal people this issue presents a rather disturbing dilemma: they wish to share knowledge, but the context has changed and knowledge now has to be protected to avoid exploitation" (McGregor 397). The interchange does not have to be confrontational, however, argue Clifford Trafzer, Willard Sakiestewa Gilbert, and Anthony Madrigal: "Using cultural science or an integrated scientific approach . . . can provide valuable insights, augmenting Western science with cultural knowledge" (1850). Because of the dominant lack of appreciation and cooperation on the part of Western science and the perceived incompatibility of Indigenous knowledge with Western science, a colonial power dynamic lingers. In her essay "Anticolonial Strategies for the Recovery and Maintenance of Indigenous Knowledge", Leanne Simpson writes of the inextricable link between colonial power and lack of respect for Indigenous knowledge. "The depoliticizing of Indigenous Peoples and TEK [Traditional Environmental Knowledge] serves to make the discussion of TEK more palatable to scientists by sanitizing it of the ugliness of 
colonization and injustice, so scientists can potentially engage with the knowledge but not the people who own and live that knowledge" (Simpson 376).

In an effort to bridge the apparent gap between differing worldviews, Pat Lauderdale suggests, more broadly, one of the values of Indigenous knowledge for a Western worldview and its science. He acknowledges that Indigenous knowledge cannot necessarily "provide all the answers to current environmental problems; however it can provide us with ideas about how to improve our questions and, therefore, improve our potential to provide more equitable, less oppressive structures from which to approach numerous problems (Lauderdale 2009 1842, my emphasis). The grammar of Lauderdale's sentences denotes an us-them dichotomy and thus implicitly reinforces the power dynamic divide between the two systems of thought. Despite this divide, however, his suggestion that ideas in general trump specific applications is valuable, and it is a consideration that I want to pursue in looking at the several American writers discussed below.

In the context of what Indigenous knowledge can offer Western science, there is the promise, of course, of new uses for the natural resources which provide commodities such as food, clothing, shelter, fire, and ingredients for pharmaceuticals. And Indigenous knowledge can certainly suggest ways the West might address its massive environmental problems. But keepers of Indigenous knowledge and several American Indian writers such as Leslie Marmon Silko (Laguna Pueblo), Linda Hogan (Chickasaw), Gerald Vizenor (Anishinaabe), Marilou Awiakta (Cherokee), and the late Vine Deloria, Jr. (Sioux), among many others, argue that ultimately the landscape or the natural world provides humans something beyond commodities, a different kind of resource, equally invaluable. Very literally and specifically, the natural environment can be seen to provide human beings their profoundest wisdom. These writers remind their readers over and over again that such stories as the Pueblo version of Enchanted Mesa insist that human survival itself ultimately depends on memory and imagination; survival and meaning depend on the wisdom that comes from stories. Survival depends as much on this wisdom, they argue, as on scientific knowledge and technological progress.

I have selected a group of writers who practice different literary genres (including film), but this selection admittedly offers only a very narrow range; it is of course somewhat arbitrary and necessarily limited. One could easily include others, such as Pamela Colorado (Oneida), Roger Echo-Hawk (Pawnee), Russell Means (Oglala Lakota Sioux), David Lester (Muscogee Creek), Gilbert Walking Bull (Lakota Sioux), Ed McGaa (Oglala Sioux), and/or Winona LaDuke (Anishinaabe), for example. Indeed, one could choose a different group of American Indian writers altogether and discover some of the same 
themes. In his essay "Indigenous Knowledge in the Decolonial Era", for example, Michael Doxtater names such writers and advocates of recovering Indigenous knowledge as Paula Gunn Allen (Laguna Pueblo), Lori Arviso Alvord (Diné/Navajo), Elizabeth Cohen Van Pelt (Diné/Navajo), Joy Harjo (Muscogee Creek), Elizabeth Cook-Lynn (Crow Creek Lakota), Ward Churchill (Cherokee), among several others (see Doxtater 620). The purpose, of course, is to refer to these writers in suggesting how different Indigenous North Americans reflect on and articulate the differences between the worldviews of Indigenous peoples and practitioners of Western science, arguing that in so doing, they are implicitly calling for a reassessment of colonial power relations.

Leslie Marmon Silko implicitly recalls the controversy over Enchanted Mesa as she suggests the importance of the "idea" of Indigenous knowledge rather than any specific immediate application, as it were. In her essay "Landscape, History, and the Pueblo Imagination: From a High Arid Plateau in New Mexico" she uses the title itself to stress immediately the importance of imagination for the Pueblo people. She states that, according to Pueblo tradition, human beings emerged only when they were able to "imagine themselves as sisters and brothers to the badger, antelope, clay, yucca, and sun" (92). Without that imaginative wisdom, she insists, there is no knowledge worth having. No emergence. No life. I will come back to this essay below, but for now, it is important to note that Silko articulates an understanding of value perhaps different from that held by mainstream Western society. Whether or not she intends a literal or figurative emergence, the idea of placing value on imagination and on story is clearly paramount.

To take a specific example of how an American Indian writer might be seen to talk back to the principles and approaches of Western science, Linda Hogan argues in her essay "A Different Yield" that in the context of scientific experiments on animals, "the loser in the conflict concerning human and animal community is science." She explains that

What we really are searching for is a language that heals this relationship, one that takes the side of the amazing and fragile life on our life-giving earth. A language that knows the corn, and the one that corn knows, a language that takes hold of the mystery of what's around us and offers it back to us, full of awe and wonder. It is a language of creation, of divine fire, a language that goes beyond the strict borders of scientific inquiry and right into the heart of the mystery itself (Hogan 59).

To suggest that Indigenous writers like Hogan and Silko offer only a vaguely mystical rendition of Indigenous knowledge, one that provides ultimately only an oppositional notion of a difference with Western science is in a sense to miss the point. Rather, Native American writers can be seen to be offering a 
fundamentally different way of looking at the world. That is, in part, what one can read in the title of Hogan's essay "A Different Yield." Hogan's assertion in itself characterizes the recovery of Indigenous knowledge and thus constitutes an empowering and a decolonizing act.

Dakota Sioux writer, theologian, historian Vine Deloria, Jr. contends in the context of Native wisdom through oral tradition versus that of Western science: "All we ask is respect for the other traditions and some of their versions of origins" (Deloria 187). All he asks, in other words, is that Western tradition share in the wisdom Native Americans have garnered from the natural environment through their longevity in a specific place. As we will see below, David Brumble has problematized Deloria's assertion by equating it with notions of the validity of Creationism. According to Deloria, "The non-Western tribal equivalent of science is the oral tradition, the teachings that have been passed down from one generation to the next over uncounted centuries" (51), yet, he argues, "Respect for non-Western traditions is exceedingly difficult to achieve" (47). "Therein lies the difficulty in approaching the oral traditions of Indians from a Western scientific perspective: instead of postponing judgment and viewing the anomaly as a prospect for future research, conclusions are drawn prematurely, are almost always in favor of rejecting the Indian account, and the usefulness of the tradition is lost" (190-91). Hence one witnesses Libbey's rejection of the oral tradition surrounding the history of Enchanted Mesa, and that rejection actually apparently influencing his science. Deloria and others ultimately argue that rejection of the wisdom contained in an oral tradition intrinsically necessitates a rejection of the peoples who define themselves through that tradition. Hence, they argue, this rejection is part and parcel of the centuries-old colonial power relation between colonists and Indigenous peoples.

Although its acceptance is only part of the point, acknowledgment of the possible validity of such Native traditions requires a leap, to be sure. Lakota leader from the late-nineteenth, early-twentieth century Black Elk articulates the paradox inherent in the belief in the truth value of oral narrative. After recounting the sacred Lakota story of the offering of the pipe, he concludes with this statement: "This they tell, and whether it happened so or not, I do not know, but if you think about it, you can see that it is true" (4). Black Elk thus suggests that there is a truth that somehow transcends the literal narrative of events. This truth is contained in the fact of the telling itself, a concept contrary to Western science, to be sure, but very much a part of contemporary American Indian writing.

The very title of Deloria's 1995 book on the subject of the clash between American Indian epistemologies and those of Western science makes explicit his bias and suggests Deloria's irreverent response to theories forwarded by Western 
science: Red Earth, White Lies: Native Americans and the Myth of Scientific Fact. Myth of fact? In any discussion of this book, one must acknowledge that Deloria includes several seemingly unfortunate reactions, such as his attempt to discredit the validity of the theory of natural selection and evolution and his frequent attacks on individual scientists rather than on the worldview of Western science itself. In the essay review of the book mentioned above, David Brumble essentially ridicules Deloria, insisting that the author is wrong on almost every page. Brumble compares Deloria's plea for a place at the scientific table with a similar rhetoric used by creationists. He calls Deloria's work ethnic pseudoscience and warns that "we should worry that Deloria's affirmative action science might work its way into public school science curricula" (Brumble 340). Given the opportunity to rebut, Deloria asserts that his book is "a critique of reactionary science and conservatism in academia", implying, I suppose, that Brumble is a conservative reactionary himself. Deloria maintains that "the basic presentation is indeed geomythology coupled with speculations that our knowledge of the world may not be correct" (Deloria, Response 348, 347).

Despite the obvious problems with the book as science, however, what is important to note is that this prominent American Indian-at the time a highly-credentialed academic, a professor of history, law, and religious studies-insists on the importance of non-Western ways of knowing and takes issue with many facets of Western science. He argues that fundamentally, like religion, Western science is a dogmatic form of belief: "Science and religion are inherited ways of believing certain things about the world", he writes. "Even the purest forms of scientific and religious expression are rooted in the unconscious metaphysics of the past, and critical examination of the roots of the basic doctrines in these areas will reveal the inadequacy of [such] beliefs" (15). Deloria argues that in contrast to Western notions of scientific objectivity "knowledge is personal for non-Western peoples" (53). He maintains, moreover, that Indigenous peoples "obtain information from birds, animals, rivers, and mountains which is inaccessible to modern science" (56). He describes a major difference between Western science and American Indian worldviews by describing what has come to be known as the Gaia hypothesis (although he does not use that terminology): he argues that the world we inhabit is itself alive, and because the earth is alive it must be thought of as one single, whole being.

Deloria asks his readers and his potential readers, scientists especially, simply "to investigate the knowledge of tribal peoples and incorporate it into modern scientific explanations" (48). He uses as one specific example the Western scientists' learning, finally, to play music to spur the growth of plants, comparing the practice with similar, long-standing Indigenous traditions. "No real discussion was ever presented regarding American Indian knowledge of plant 
life, even though it is well known that Corn Dances are one of the chief religious ceremonies of the southwestern Indians" (59). In another instance, he argues for the importance of learning from animals: "Why didn't people take Indians seriously when we said that animals and birds give us information on medicinal plants?" (59). If not scientists, at least some non-Native writers are listening. Nature writer Barry Lopez, for example, makes much the same point as Deloria in his 1978 essay "The Passing Wisdom of Birds", writing that "The insights of aboriginal peoples are of inestimable value . . . in rethinking our relationships with the world" (Lopez 198). Therefore, he continues, "we need to seek an introduction to the reservoirs of intelligence that native [sic] cultures have preserved in both oral tradition and in their personal experience with the land" (203). We know, of course, that Western science does indeed "learn" from non-human animals. But in response to the practices of scientists, Deloria, like Hogan, suggests that it is the wrong kind of learning; he maintains that "If scientists really believed in the unity and interrelatedness of all things, their emphasis would shift dramatically and they would forswear using animals for lab research, change their conception of agronomy entirely, do considerably different studies of water and landscapes, and begin to deal seriously with the by-products of their experiments" (57). That is, he asserts, Western scientists oblivious to what non-human nature might actually have to teach them. Deloria's assertion reminds us of Lauderdale's notion of how an appreciation of Indigenous knowledge can provide ideas about how to improve the way scientists ask questions.

In contrast to Deloria, non-Native anthropologist, Brown University academic, Shepard Krech argues in The Ecological Indian (1999) and elsewhere, to a very wide audience, that Native Americans were not and should not be considered ecologists or conservationists. To make his argument, in the instance of the American buffalo of the Great Plains, he delineates what he sees as the Native American contribution to the near total extermination of bison bison. Following a previous chapter in which he blames Indigenous peoples for the extermination of large North American mammals of the Pleistocene, Krech describes the destruction of the massive North American bison herds and the near extinction of the species during the nineteenth century. To make his point, Krech relies adroitly on Western ways of knowing: population counts, statistics, history, biology. Yet along the way, he goes to great lengths to denigrate pre-Columbian Native hunting practices and to demean the participants in such hunts. In a later essay Krech reiterates his accusation, insisting that "the evidence for conservation prior to the pervasive influence of people of European descent" remains "slight" (Krech "Reflections" 81). There is, however, an astounding paradox in his argument. Namely, he insists that these non-conservationist Indigenous hunting practices 
actually endured for millennia. That is, he notes that the "ancient technique used to kill buffaloes [went on] for well over eleven thousand years" (Ecological 143). That these Indigenous hunting practices could endure for eleven thousand years demonstrates emphatically that such methods were indeed sustainable, were indeed conservationist, were indeed environmentally sound. Meanwhile, as Krech also acknowledges, after these many millennia of sustainable Indigenous hunting practices, what ultimately nearly doomed the buffalo were neither buffalo jumps, nor flint spears and arrows, nor fires, nor competition with the Plains Indians' grazing horses. Rather, the near-extinction of the American buffalo is directly and indisputably linked to a mere seventeen years of non-Native European American hunting practices. These practices enabled hunters to decimate herds of tens of millions of buffalo, between 1867 and 1884. By 1884, writes Krech, "with very few exceptions, the buffalo was gone" (141). Today's buffalo population derives primarily from just a relatively few animals which survived the rampage by escaping, for example, into the wilds of what has become Yellowstone National Park (by 1872) or by being rounded up by a few foresighted cowboys and penned for safe keeping and breeding.

The lesson here, for Native writers like Deloria, is not only that the science Krech uses is sometimes inadequate or at least very questionable (take for example his Native population estimates, absolutely the lowest available), but also that it privileges non-Native perspectives. Indeed, in making his argument, Krech seems to need to demonize, demean, and diminish Native Americans and their wisdom as regards natural resources. He also diminishes their very presence on the continent, suggesting that there were possibly as few as four million inhabitants in North America at the time of European contact (Krech "Reflections" 80). In "American Indian Environmental Religions", Christopher Vecsey offers an alternative to Krech by arguing that we "cannot accept the conception of Indians as conservationists in a modern Western sense. We must understand Indians' environmental attitudes on their own terms" (Vecsey 6). Despite such recognition of alternative viewpoints, however, it is Krech's book, both an economic and academic success, which thus becomes the "scientific" text with which to contend. Krech's is the argument that becomes widespread. Its rhetoric becomes fact in the popular mind; hence the need and rationalization for a subtitle such as Deloria's: "The Myth of Scientific Fact". According to Native American writers like Deloria, just so goes mainstream science in general: it excludes other ways of seeing, of thinking, and of knowing. Hence it is colonizing science. Of Krech's book in particular Deloria writes that the argument is "nonsense.... The Indians did not make any appreciable dent in buffalo numbers in the Northern Plains. It's anti-Indian stuff" (qtd. in TallBear 2). In what is primarily a favorable review of Krech's book, Kimberly TallBear concludes by returning to a connection between 
science and colonialism: "the principle difference between us lies in the difference between grappling with and throwing off the yoke of colonization versus coming from a culture that was born of and grew from the fruits of colonization. This is a distinction that Krech does not substantively address in this book" (4). In this context, then, one can see that expressing discontent with Krech's book and method, as Deloria and other American Indians do, is actually a decolonial act.

Chickasaw poet, novelist, and activist, Linda Hogan responds not to the slaughter and near extinction of buffalo through Western hunting practices and attitudes of European Americans, but to the hunting of whales. She has studied in great detail the gray whale in particular, and has co-authored a work entitled Sightings: The Gray Whale's Mysterious Journey (2002). Culled from her research and her activism and inspired by the actual controversial Makah whale hunt of 1999, she has also published a novel, a fictional account of just such a hunt. In the novel, entitled The People of the Whale (2008), Hogan suggests an epistemology similar to that suggested by Deloria. In one passage, for instance, a character contemplates the diminishing numbers of whales along the northwest coast of Washington state: "He remembers when the whales used to pass by in great numbers. He would watch one, its great shining side, the eye with its old intelligence, the gentleness of it in the body covered with barnacle life and creatures. It was loved by his people. It was a planet. When they killed it, he thinks perhaps they killed a planet in its universe of water" (Hogan, People, 267). The passage suggests very specifically the concept of a living planet, that the planet as whole is a single, living entity. This killing, she suggests in Sightings, is a result of not listening to the elders, specifically older women, who insist on an identity relationship with the whale. They have been silenced, she argues. Their wisdom has been disregarded (Sightings 154). Hogan argues that wisdom, imagination, memory, story, these are all needed to keep the balance in a fragile world, and she looks to a precolonial philosophy to bolster her argument.

In fiction as well as in non-fiction essays by Hogan and others, then, American Indian writers can be seen to investigate the differences in worldviews between mainstream Western science and Native American belief systems and to challenge the former. In the novel The Grass Dancer, as another example from a work of fiction, Dakota Sioux writer Susan Power contrasts the literal 1969 Apollo 11 moon landing with what she perceives as an alternate reality. As in many instances throughout the novel, Power offers apparent reversals of mainstream thinking in order to make her point. Regarding the moon landing specifically, the novel seems to insist that, along with Aldrin and Armstrong, the Dakota woman Margaret Many Wounds walked on the moon that July day in 1969. This move on 
Power's part is both feminist and Nativist and is thus also decolonial; in putting a Native American woman on the moon, she challenges the white male hegemony of the West, of the Gemini program, and of the science that enabled the moon shot in the first place. Hers is a decolonizing act.

The narrative technique Power uses prepares the reader for Margaret Many Wounds's moonwalk, where Power presents the possibility of two different, but parallel, realities. To do this, the author presents the landing of the manned Apollo module - the event that is clearly real from a mainstream perspective-as in fact miraculous. In contrast to the miracle of the actual landing, she presents Margaret's moonwalk as completely mundane. That is, several characters refer to this Apollo 11 event as a miracle, as something that appears inexplicable by the laws of nature, in contrast to Margaret who has, quite simply, and in this context quite literally, been to the moon. Power complicates the mainstream reader's response, that is, by reversing and thus problematizing the very concept of miracle. After every special news report, for instance, Evie's husband Philbert repeats that the moon landing is "gonna be a miracle" (102). Evie also thinks it miraculous, and like a doubting Thomas, she needs to see it to believe it: "Evie was desperate for the astronauts to leave their vehicle and walk on the moon. She wanted to see it happen and know it was real: a scientific miracle worked out with equations. 'It will be history', she said aloud" (115). "It's all history", Margaret, her mother, tells her (114-15). With this statement the mother articulates the disparity between her own Dakotan and the mainstream conceptions of history and, in a sense, of mainstream science. Margaret is able to acknowledge that both worldviews constitute history, both are valid.

Margaret tells her daughter matter-of-factly that she really was there, "looking back at the spinning earth, bright as a blue eye" (113). Even though the reader might do well to doubt the literal validity of Margaret's story, Susan Power the author complicates the issue in reporting Evie's response: "Years before, she [Evie] would have treasured this anecdote [about her mother's walking on the moon], but it had come too late for her to enjoy or believe" (113). The implicit suggestion is that Evie's (and hence the reader's) inability to believe that Margaret had walked on the moon is her own shortcoming. Rather than any inherent unreality of the event itself, that is, it is a lack in the witness's powers of perception. In this context, Evie's inability to believe says more about her mindset and worldview than about the scientific or historical facts themselves. Her inability in this context defines who she is. The exchange between mother and daughter suggests that Evie has been away from her people too long; she has lost the ability to believe her mother's story because she has lost the ability to perceive this alternate reality. The implication is that the reader too might suffer from a similar failure of imagination, as well as from a failure of perception. Susan Power concludes her novel by portraying the 
character Herod, an elder, as one who insists on the importance of telling both stories. Talking with a new non-Native mother about her mixed-blood baby, Herod reminds the mother that the baby "needs to know both sides. Otherwise she'll stand off-balance and walk funny and talk out of one side of her mouth. Tell her two stories" (314). It is important to reiterate at this point that Susan Power's fictional account does not need to present a literal truth concerning Margaret's moon walk. What is important is that it demands of the reader a willingness to accept alternate ways of interpreting the physical reality and perceptions of that reality and challenge Western dominance. The author's demand is similar to Vine Deloria, Jr's when he insists on the need "to investigate the knowledge of tribal peoples and incorporate it into modern scientific explanations" (Deloria 48).

Cherokee poet Marilou Awiakta makes a very similar point concerning the fusion of science and Native epistemology in her prose poem "Amazons in Appalachia." She writes that "According to Albert Einstein, there is a dimension beyond time/space where time stands still—past, present, and future are one. My Cherokee ancestors knew how to enter this dimension at will" (Awiakta 125). Awiakta's implicit suggestion here is that only with Einstein does Western science catch up with a Native American epistemology. In this piece Awiakta argues that the spirits of her ancestors "abide in [her] native mountains in East Tennessee... I walk with the strong, nurturing grandmothers" (Awiakta 125). Although an obvious point Awiakta makes concerns the need for and power of women, she also suggests the idea that Cherokee people have, as they have had, access to a dimension that science and scientists can only speculate about. It is important to note that Awiakta, like Silko and Hogan, for example, implies a worldview that stands in direct contrast to that of Western thinkers and scientists. She provides the idea of a "dimension" that Western ways of thinking simply do not allow access to.

In this sense, Awiakta presents a moment similar to the one Susan Power presents with Margaret's moonwalk. The assertion itself challenges the authority and exclusivity of Western science and thus tends to decolonize. Certainly, one cannot "test" the validity of Awiakta's assertions. That's not the point. Rather, one can recognize that through her poetry, she offers a different way of envisioning the world, a worldview in which such transcendence is possible. She provides her readers with ideas about how to improve or ask appropriate questions.

In yet another instance in "Amazons in Appalachia", Awiakta makes the argument, similar to Susan Power's noted above, that Western tradition, represented here by "white men", fails to see the importance of balance, of taking different points of view, of allowing multiple perspectives, in order to maintain balance.

"Where are your women?"

The speaker is Attakullakulla, a Cherokee chief renowned for his shrewd and effective diplomacy. He has come to negotiate a treaty with the whites. Among 
his delegation are women "as famous in war as powerful in the Council." Their presence also has ceremonial significance: it is meant to show honor to the other delegation. But that delegation is composed of males only. To them the absence of their women is irrelevant, a trivial consideration.

To the Cherokee ... reverence for women/Mother Earth/life/spirit is interconnected. Irreverence for one is likely to mean irreverence for all. Implicit in their chief's question, "Where are your women?" the Cherokee hear, "Where is your balance? What is your intent?" They see that the balance is absent and are wary of the white men's motives. They intuit the mentality of destruction. (92)

In the poem "Where Mountain and Atom Meet", the poet suggests the relationship between Western science (that enabled splitting atoms) and Indigenous knowledge. She insists that aside from science there exists "a deeper kind of knowing" (72), a knowing and wisdom that Native people can be privy to. As others have suggested, this knowledge or wisdom results in part from long-term residence in a single, specific location. Through longevity in a single place, they gain access to a deeper kind of knowing. In another context, Winona LaDuke makes a very similar assertion. She submits that Indigenous knowledge derives from a spiritual connection and "on generations of careful observation within an ecosystem" (LaDuke 127).

A few lines from another Marilou Awiakta poem, "When Earth Becomes an 'It"' suggest a distinction between different ways of knowing, different ways of understanding the world, different epistemologies. At the same time, however, Awiakta seems to insist on the need for mutual exchange, seems to acknowledge everyone's need for allies. And in common with the other American Indian writers discussed above, the speaker in Awiakta's poem suggests that life itself depends on the ability to enjoy alternative worldview.

When the people call Earth "Mother",

they take with love

and with love give back

so that all may live.

When the people call Earth "it",

they use her

consume her strength.

Then the people die. (6; Awiakta's emphasis)

If we see the Native American argument about the importance of recognizing different or both or alternate stories in Deloria, Silko, Power, Awiakta, and others, we also see it presented, albeit playfully, in Native American film. In his 1987 film Harold of Orange, Gerald Vizenor (Anishinaabe) seems to have great fun with the scientific theories concerning the Bering Land Bridge hypothesis of 
Indigenous migration. Two ways of understanding are made manifest through Vizenor's two different characters: one American Indian, New Crows; the other, Andrew, a European American. They discuss "origin theories":

ANDREW: I have considered the origin theories of the American Indians . . . some are quite interesting. I find the Bering Strait migration theory to be the most credible... How about you then, what are your thoughts on the subject?

NEW CROWS: Which way, east or west?

ANDREW: Which way? What do you mean?

NEW CROWS: Which way across the Bering Strait, then?

ANDREW: Yes, I see. ... Well, I hadn't really thought about it that way. Which way do you think?

NEW CROWS: From here to there, we emerged from the flood here, the first people, unless you think we are related to the panda bear.

ANDREW: Oh, not at all, not at all . . actually, what you say makes a great deal of sense, but the problem I seem to have, you see, is that there is so little evidence to support your idea...

NEW CROWS: Jesus Christ was an American Indian ...

ANDREW: Was he now, who would have guessed?

The sheepish response of the character Andrew (Alan Woodward) to the panda bear question that New Crows (DeForest White Eagle) puts to him enables screenplay writer Vizenor to fuse Andrew's underlying racist attitude with a somewhat playful challenge to the scientific Bering Land Bridge theory. The exchange highlights the differences between two worldviews yet implies that the Native worldview is at least open to considering the land bridge theory, though reversed. The apparent absurdity of New Crows's assertion that Jesus Christ was American Indian further underscores the irony of the situation. New Crows takes a figure from a religious belief system (rather than from history or science, for example) and offers it, ironically, as scientific evidence, proof even, of something completely unrelated-origin or migration theories of Indigenous North Americans. Vizenor's rhetorical move-which at first might appear simply ironic and playful, actually anticipates Deloria's very serious and sober contention that science and religion both have their dogmas and both require leaps of faith. Given this scene in the film, one can argue that though his methods are different, Vizenor makes the same assertion.

When Andrew maintains that "there is so little evidence", he is clearly relying on a science model for the understanding of history. His argument is reductively circular in that he maintains that science does not support a non-scientific assertion. When New Crows makes his claim that Jesus Christ was an American Indian, Andrew pulls back completely, crosses his arms, and looks 
away from New Crows. Thus, body language suggests that there is evidently an impasse, that from his perspective there can be no reconciliation of belief systems. Andrew's body language and specific gesture mark the end of the communication. The scene implies that Andrew is confined, limited, and alienated by his Western worldview, whereas New Crows, who smiles and gets smiling affirmation from those sitting across from him, has the support of the community, which in this specific instance is made up of both a Native American and a European American. Despite the scene's comic effect, Andrew's body language offers a perhaps subtle non-comic message that is compounded in other scenes throughout the film. The Western gaze limits the people's ability to appreciate alternative worldviews. In that the film as a whole examines the colonial relationship between a non-Indian granting agency and the grant proposal a group of Indians submit, this scene too can be regarded as anti- or decolonial. Like the film as a whole, that is, this scene calls attention to the power imbalance between colonizer and reservation Indians by presenting a reversal of that entrenched power dynamic in which whites have not only the money but also the exclusive rights to history and science.

In a more recent film, Four Sheets to the Wind (2007) Creek director and writer Sterlin Harjo presents a scene which cleverly mocks the stereotype of Indian spiritual powers and innate, intimate knowledge of the natural world. In so doing, this film, like Vizenor's, calls attention to the dominant culture's ways of holding and dispensing knowledge. The son and nephew of a man who has just died discuss the dead man's life. The nephew Jim (Jon Proudstar) tells Cufe (Cody Lightning) the following anecdote about the young man's father, recalling how Cufe's father stopped a tornado from coming:

JIM: Your dad was a funny guy. I remember this one time ... there was this tornado warning, and I was freaking out, crying and shit, and he came over to me and told me not to worry, that he knew a dance that was going to protect us from the tornado, and he went out into the front yard started dancing and singing and shit, and that tornado, it never came. When I was older your mom told me he was watching the weather channel. ... He knew that tornado was never coming. (Four Sheets)

Most immediately this scene demonstrates the ability of these Native American characters to laugh at themselves and at the stereotypes imposed upon them. Clearly, they have fun with and in fact make fun of stereotypes of Native mysticism and spirituality. But at the same time, this is a film in which the stories are passed down by word of mouth, the oral narratives play a very important role; the father lives through the stories that the survivors tell about him. In brief then, there is an irony in the science versus mysticism in this film similar to that of the Vizenor film. At the same time, however, if knowledge is power, 
it is important that the Indian man described in this scene is able to work both sides of the knowledge dichotomy. He acknowledges the power of the dance, when he uses a weather report derived from Western science to "protect" his extended family from the storm. Both this film and the Vizenor film cogently raise the issue of the place of science and empirical fact in a world in which there are other ways of knowing, other ways of perceiving reality, other ideas about what questions to ask and how to ask them.

As mentioned at the outset, Laguna Pueblo novelist and essayist Leslie Marmon Silko, in her essay "Landscape, History, and the Pueblo Imagination", writes about the importance and scientific potential of Native America's oral traditions. Hunting stories, she maintains, "contained information of critical importance about behavior and migration patterns of mule deer. Hunting stories carefully described key landmarks and locations of fresh water. Thus a deer-hunt story might also serve as a map" (88, my emphasis). In addition to a story's being immediately and significantly important in that it might provide information about where to get drinking water, for instance, Silko asserts that such stories contain actual scientific information about animal behavior, gained through generations of interaction with the hunted animals. The Pueblo hunters and storytellers, in short, have done the field work; it is up to Western scientists to appreciate their findings. More generally, Silko suggests, for example, that the "narratives linked with prominent features of the landscape between Paguate and Laguna delineate the complexities of the relationship which human beings must maintain with the surrounding natural world if they hope to survive in this place, especially because 'Survival in any landscape, she argues, "comes down to making the best use of all available resources" (90). Because of the link between landscape features and narrative, "the journey was an interior process of the imagination, a growing awareness that being human is somehow different from all other life_-animal, plant, and inanimate" (91). But for Silko, there is no exclusive acceptance of Western epistemologies. She writes in this context that even though different from other life forms, humans and non-humans alike are "all from the same source: the awareness [of difference] never deteriorated into Cartesian duality, cutting off the human from the natural world" (92). Indeed, for Silko, as noted above, "Life on the high arid plateau became viable when the human beings were able to imagine themselves as sisters and brothers to the badger, antelope, clay, yucca, and sun. Not until they could find a viable relationship to the terrain, the landscape they found themselves in, could they emerge" (92). Like Deloria and other Native American writers and scholars, then, Silko too emphasizes the importance of non-Western ways of knowing, and she advocates the blending of those different ways. From atop the mesa, for instance, perhaps from atop Enchanted Mesa just south of her home at Laguna, 
she argues, one can see that "So little lies between you and the sky. So little lies between you and the earth. One look and you know that simply to survive is a great triumph, that every possible resource is needed, every ally-" (94).

\section{Sources Cited}

AWIAKTA, Marilou. Selu: Seeking the Corn-Mother's Wisdom. Golden, Colorado: Fulcrum Publishing, 1993.

BANDELIER, Adolph Francis Alphonse. Papers of the Archeological Institute of America. Am. ser., I.v, Final Report, II, Cambridge, 1892. 313-314.

BLACK ELK, with John G. NEIHARDT. Black Elk Speaks. Albany: State University of New York Press, Excelsoir Editions, 2008.

BRUMBLE, David H. "Vine Deloria, Jr, Creationism, and Ethnic Pseudoscience." American Literary History 10.2 (summer 1998): 335-46.

CAJETE, Gregory. Native Science: Natural Laws of Interdependence. Sante Fe: Clear Light Press, 2000.

COLORADO, Pamela. "Bridging Native and Western Science." Convergence 21.2 \& 3 (1988): 49-68.

DELORIA, Vine Jr. Red Earth, White Lies: Native Americans and the Myth of Scientific Fact. New York: Scribner, 1995.

. "Response to David Brumble." American Literary History 10.2 (summer 1998): 347-49.

DOXTATER, Michael G. "Indigenous Knowledge in the Decolonial Era." American Indian Quarterly 28.3\&4 (2004): 618-33.

Four Sheets to the Wind. 2007. Indion Entertainment Group. Dir. Sterlin Harjo. Screenplay: Sterlin Harjo.

GORDON, David \& Shepard KRECH III. Indigenous Knowledge and the Environment in Africa and North America. Athens: Ohio University Press, 2012.

Harold of Orange. 1984. Film in the Cities. Dir. Richard WEISS. Screenplay: Gerald Vizenor.

HODGE, Frederick Webb. "Enchanted Mesa." National Geographic 8.9 (October 1897): 273-84.

. Letter. Washington, D.C: June 8, 1899.

- "The Verification of a Tradition." American Anthropologist 10.9 [old series] (September 1897): 299-302.

HOGAN, Linda. “A Different Yield.” Dwellings. New York: Touchstone, 1995. $47-62$.

- The People of the Whale. New York: Norton, 2008.

. Sightings: The Gray Whale's Mysterious Journey. Washington, DC:

National Geographic, 2002. 
KRECH, Shepard III. The Ecological Indian: Myth and History. New York: Norton, 1999.

. "Reflections on Conservation." American Anthropologist 107.1 (March 2005): 78-86.

LADUKE, Winona. "Traditional Ecological Knowledge and Environmental Futures." Colorado Journal of International Environmental Law and Politics. Endangered Peoples: Indigenous Rights and the Environment. Niwot: University of Colorado Press, 1994.

LAUDERDALE, Pat. "Collective Indigenous Rights and Global Social Movements in the Face of Global Change: From Resistance to Social Change." Journal of Developing Societies 25.3 (July-September 2009): 371-91.

. "Indigenous Peoples in the Face of Globalization." American Behavioral Scientist 51.12 (2008): 1836-43.

LOPEZ, Barry. "The Passing Wisdom of Birds." Crossing Open Ground. New York: Scribner's, 1988. Rpt. New York: Vintage, 1989. 193-208.

LUMMIS, Charles. The Land of Poco Tiempo. 1893. Rpt. Albuquerque: University of New Mexico Press, 1952. Rpt. 1975.

MCGREGOR, Deborah. "Coming Full Circle: Indigenous Knowledge, Environment, and Our Future." American Indian Quarterly 28.3\&4 (2004): 385-410.

POWER, Susan. The Grass Dancer. New York: Putnam, 1994. Rpt. New York: Berkeley, 1995.

ROBERTS, Karen. Circumpolar Aboriginal People and Co-Management Practice: Current Issues in Co-Management and Environmental Assessment. Calgary: Arctic Institute of North America, 1996.

SILKO, Leslie Marmon. "Landscape, History, and the Pueblo Imagination: From a High Arid Plateau in New Mexico." Antaeus 51 (1986): 83-94.

SIMMONS, Marc. "Trail Dust: The Enchanted Mesa: Myth of True Tale?" The Santa Fe New Mexican (20 May 2006): np.

SIMPSON, Leanne R. "Anticolonial Strategies for the Recovery and Maintenance of Indigenous Knowledge." American Indian Quarterly 28.3\&4 (2004): 373-84.

TALLBEAR, Kimberly. “Shepard Krech's The Ecological Indian: One Indian's Perspective." International Institute for Indigenous Resource Management (September 2000): 1-5. http://www.iiirm.org/publications/Book\%20Reviews/Reviews/Krech001.pdf

TRAFZER, Clifford E, Willard SAKIESTEWA GILBERT \& Anthony MADRIGAL. "Integrating Native Science into a Tribal Environmental Protections Agency." American Behavioral Scientist 51(2008): 1844-66.

VECSEY, Christopher. "American Indian Environmental Religions." Christopher VECSEY, Christopher \& Robert W. WENABLES, eds. American Indian 


\title{
Environments: Ecological Issues in Native American History. Syracuse: Syracuse University Press, 1980. 1-37. 175-84. \\ WILSON, Angela Cavender. "Introduction: Indigenous Knowledge Recov- ery is Indigenous." American Indian Quarterly 28: 3\&4 (2004): 359-72.
}

\begin{abstract}
Using as a starting point an example of when science and legend butt heads, this paper proposes that according to many Native American writers there is a persistent need for all people, scientists and storytellers alike, to recognize that the natural environment provides something in addition to its natural resources. That is, these Native writers as well as practitioners of Indigenous knowledge teach that-in addition to the commodities of food, clothing, shelter, fire, pharmaceuticals, etc-the environment very literally and specifically provides humans their profoundest wisdom. Whether told from or about a mesa, a prairie, a rainforest, or an ocean, insist American Indian writers such as Leslie Marmon Silko (Laguna Pueblo), Linda Hogan (Chickasaw), and the late Vine Deloria, Jr. (Sioux), the stories insist that survival ultimately depends on imagination and memory, on a wisdom gleaned from nature, as much as on scientific progress and technological invention.
\end{abstract}

Keywords: American Indian literature, Indigenous knowledge, human ecology, environmental ethics, North American Indian land ethic, sustainable conservation practices, environmental history.

Résumé : Partant d'un exemple de conflit entre science et légende, cet article avance que, selon de nombreux écrivains amérindiens, la nature nous fournit davantage que ses simples ressources matérielles. Cela revient à dire que, selon ces écrivains dépositaires de savoirs indigènes, outre la nourriture, les vêtements, le feu, l'habitat ou les produits pharmaceutiques, la nature nous fournit littéralement la sagesse. Ces histoires, qu'elles parlent d'une « mesa », de la prairie, de la forêt ou de l'océan et qu'elles soient contées par Leslie Marmon Silko (Laguna Pueblo), Linda Hogan (Chickasaw) ou le regretté Vine Deloria Jr (Sioux), insistent toutes sur le fait que la survie finalement dépend de l'imagination et de la mémoire, d'une sagesse glânée dans la nature, tout autant que du progrès technique.

Mots-clés : Littérature amérindienne, Savoirs indigènes, Écologie humaine, Éthique de l'environnement, Éthique amérindienne de la terre, Pratiques de préservation durables, Histoire environnementale.

Lee Schweninger is a professor of English at the University of North Carolina Wilmington where he teaches early American and American Indian literatures and serves as coordinator of the Native American Studies minor. His recent publications include Listening to the Land: American Indian Literary Responses to the Landscape (U. Georgia Press, 2008); The First We Can Remember: Colorado Pioneer Women Tell Their Stories (U. Nebraska Press, 2011), and Imagic Moments: North American Indigenous Film (U. Georgia Press, 2013). He has also recently published essays or book chapters on American Indian literature and/or film in The Memory of Nature in Aboriginal, Canadian and American Contexts (Ed. Francoise Besson, Cambridge Scholars Publishing, 2014), Elohi (journal, U.P. of Bordeaux, France, 2013); Critical Insights: The American Dream (Ed. Keith Newlin, Salem Press 2013); and Indigenous Rights in the Age of the UN Declaration (Ed. Elvira Pulitano, Cambridge U. Press, 2012).

Lee Schweninger est Professeur au Département d'Anglais de I'Université de Wilmington, Caroline du Nord. Il y enseigne la littérature amérindienne et coordonne le programme d'études amérindiennes. Parmi ses publications récentes, on peut citer Listening to the Land: Native American Literary Responses to the Landscape (U. Georgia P., 2008), The First We Can Remember: Colorado Pioneer Women Tell Their Stories (U. Nebraska Press, 2011) et Imagic Moments: Indigenous North American Film (U. Georgia P., 2013). II a également récemment publié plusieurs essais ou chapitres d'ouvrages sur la littérature amérindienne et/ou le cinéma dans The Memory of Nature in Aboriginal, Canadian and American Contexts (Ed. Francoise Besson, Cambridge Scholars Publishing, 2014), Elohi (revue, U. Bordeaux-Montaigne, 2013); Critical Insights: The American Dream (Ed. Keith Newlin, Salem Press, 2013); et Indigenous Rights in the Age of the UN Declaration (Ed. Elvira Pulitano, Cambridge U. Press, 2012). 